\title{
Front Matter: Volume 11805
}

, "Front Matter: Volume 11805," Proc. SPIE 11805, Spintronics XIV, 1180501 (17 August 2021); doi: 10.1117/12.2606466

SPIE Event: SPIE Nanoscience + Engineering, 2021, San Diego, California, United SPIE. States 


\section{PROCEEDINGS OF SPIE}

\section{Spintronics XIV}

Henri-Jean M. Drouhin

Jean-Eric Wegrowe

Manijeh Razeghi

Henri Jaffrès

Editors

1-5 August 2021

San Diego, California, United States

Sponsored and Published by

SPIE 
The papers in this volume were part of the technical conference cited on the cover and title page. Papers were selected and subject to review by the editors and conference program committee. Some conference presentations may not be available for publication. Additional papers and presentation recordings may be available online in the SPIE Digital Library at SPIEDigitalLibrary.org.

The papers reflect the work and thoughts of the authors and are published herein as submitted. The publisher is not responsible for the validity of the information or for any outcomes resulting from reliance thereon.

Please use the following format to cite material from these proceedings:

Author(s), 'Title of Paper," in Spintronics XIV, edited by Henri-Jean M. Drouhin, Jean-Eric Wegrowe, Manijeh Razeghi, Henri Jaffrès, Proc. of SPIE 11805, Seven-digit Article CID Number (DD/MM/YYYY); (DOI URL).

ISSN: 0277-786X

ISSN: 1996-756X (electronic)

ISBN: 9781510644489

ISBN: 9781510644496 (electronic)

Published by

SPIE

P.O. Box 10, Bellingham, Washington 98227-0010 USA

Telephone +1 3606763290 (Pacific Time)

SPIE.org

Copyright @ 2021 Society of Photo-Optical Instrumentation Engineers (SPIE).

Copying of material in this book for internal or personal use, or for the internal or personal use of specific clients, beyond the fair use provisions granted by the U.S. Copyright Law is authorized by SPIE subject to payment of fees. To obtain permission to use and share articles in this volume, visit Copyright Clearance Center at copyright.com. Other copying for republication, resale, advertising or promotion, or any form of systematic or multiple reproduction of any material in this book is prohibited except with permission in writing from the publisher.

Printed in the United States of America by Curran Associates, Inc., under license from SPIE.

Publication of record for individual papers is online in the SPIE Digital Library.

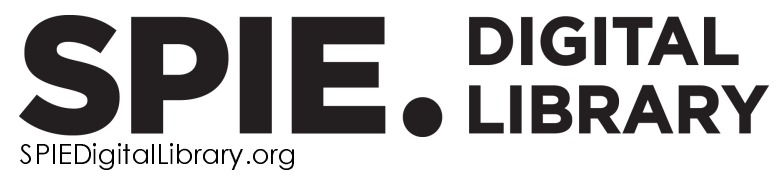

Paper Numbering: A unique citation identifier (CID) number is assigned to each article in the Proceedings of SPIE at the time of publication. Utilization of CIDs allows articles to be fully citable as soon as they are published online, and connects the same identifier to all online and print versions of the publication. SPIE uses a seven-digit CID article numbering system structured as follows:

- The first five digits correspond to the SPIE volume number.

- The last two digits indicate publication order within the volume using a Base 36 numbering system employing both numerals and letters. These two-number sets start with $00,01,02,03,04$, $05,06,07,08,09,0 A, 0 B \ldots$ OZ, followed by 10-1Z, 20-2Z, etc. The CID Number appears on each page of the manuscript. 


\section{Contents}

SPIN HALL EFFECT I

1180502 Spatial evolution of polarization in the spin Hall effect of light on reflection (Invited Paper) [11805-1]

MAGNETIC INERTIA AND NUTATION

$11805 \mathrm{OE} \quad$ Nutation wave as a platform for ultrafast spin dynamics in ferromagnets (Invited Paper)

[1 1805-22]

$118050 \mathrm{O}$ Inertial magnetization dynamics of ferromagnetic nanoparticles including thermal agitation (Invited Paper) [1 1805-24]

SPIN LASERS I

11805 OW Integrated spin-lasers for ultrafast polarization modulation (Invited Paper) [1 1805-38]

$118050 X \quad$ Frequency characteristics of the polarization self-modulation in oxide-confined vertical-cavity surface-emitting lasers (Invited Paper) [1 1805-39]

SPIN LASERS II

1180512 Spin-VCSELs for analog radio-over-fiber systems in 5G and beyond (Invited Paper) [1 1805-42]

MAGNETISM AND CHIRALITY II

1180515 Engineering parafermions in helical Luttinger liquids (Invited Paper) [1 1805-49]

SPIN LOGIC AND DEVICES

1180519 Reinforcement learning approach for deterministic SOT-MRAM switching (Invited Paper) [1 1805-53] 
SEMICONDUCTOR SPINTRONICS AND VALLEYTRONICS

$118051 \mathrm{R} \quad$ The spin-1 equivalent homomorphism of group SU(2) to group SO(3) from observer's mathematics point of view (Invited Paper) [1 1805-73]

TUNNELING PHENOMENA

$118051 \mathrm{~T} \quad$ Density functional theory analysis of symmetry-filtering scandium nitride magnetoresistive junctions (Invited Paper) [1 1805-75] 